\title{
A review of the weevil fauna (Coleoptera, Curculionoidea) of Araucaria angustifolia (Bert.) O. Kuntze (Araucariaceae) in South Brazil ${ }^{1}$
}

\author{
Roland Mecke ${ }^{2} \&$ Maria Helena M. Galileo ${ }^{3}$ \\ 1 Part of the BMBF-DLR project 01LT0011/7. \\ ${ }^{2}$ Zoologisches Institut, LS Entwicklungsphysiologie, Universität Tübingen, Auf der Morgenstelle 28, 72076 Tübingen, \\ Germany. E-mail: roland.mecke@t-online.de \\ ${ }^{3}$ Museu de Ciências Naturais, Fundação Zoobotânica do Rio Grande do Sul. Caixa Postal 1188, 90001 -970 Porto Alegre, \\ Rio Grande do Sul, Brasil.
}

\begin{abstract}
The beetle superfamily Curculionoidea includes 43 species associated with Araucaria angustifolia trees in South Brazil. These weevil species belong to the families Nemonychidae (Brarus Kuschel, 1997, Rhynchitoplesius Voss, 1952), Brentidae (Taphroderes Schönherr, 1826) and Curculionidae, the latter including the subfamilies Curculioninae (Heilipodus Kuschel, 1955, Spermologus Schönherr, 1843), Cossoninae (Araucarius Kuschel, 1966, Eurycorynophorus Voss, 1964), Scolytinae (Ambrosiodmus Hopkins, 1915, Araptus Eichhoff, 1871, Cnesinus LeConte, 1868, Corthylus Erichson, 1836, Cryptocarenus Eggers, 1936, Hypothenemus Westwood, 1834, Monarthrum Kirsch, 1866, Pagiocerus Eich hoff, 1868, Phloeotribus Latreille, 1896, Pityophthorus Eichhoff, 1864, Xylechinosomus Schedl, 1963, Xyleborus Eichhoff, 1864, Xyleborinus Reitter, 1913) and Platypodinae (Cenocephalus Chapuis, 1865, Platypus Herbst, 1893, Tesserocerus Saunders, 1836). A checklist of all species including remarks on their life histories and taxonomic notes are presented. In addition, a key for the identification of adult Curculionoidea associated with Araucaria angustifolia to genus or species level is provided.
\end{abstract}

KEY WORDS. Key.

RESUMO. A superfamília Curculionoidea compreende 43 espécies associadas à Araucaria angustifolia no sul do Brasil. As espécies destes gorgulhos pertencem às famílias Nemonychidae (Brarus Kuschel, 1997, Rhynchitoplesius Voss, 1952), Brentidae (Taphroderes Schönherr, 1826) e Curculionidae, (Curculioninae: Heilipodus Kuschel, 1955, Spermologus Schönherr, 1843; Cossoninae: Araucarius Kuschel, 1966, Eurycorynophorus Voss, 1964; Scolytinae: Ambrosiodmus Hopkins, 1915, Araptus Eichhoff, 1871, Cnesinus LeConte, 1868, Corthylus Erichson, 1836, Cryptocarenus Eggers, 1936, Hypothenemus Westwood, 1834, Monarthrum Kirsch, 1866, Pagiocerus Eich hoff, 1868, Phloeotribus Latreille, 1896, Pityophthorus Eich hoff, 1864, Xylechinosomus Schedl, 1963, Xyleborus Eichhoff, 1864, Xyleborinus Reitter, 1913; Platypodinae: Cenocephalus Chapuis, 1865, Platypus Herbst, 1893, Tesserocerus Saunders, 1836). Apresenta-se uma lista de todas as espécies, bem como informações sobre biologia e taxonomia das mesmas. Adicionalmente, está incluída uma chave de identificação de gêneros e espécies dos adultos de Curculionoidea associados à Araucaria angustifolia.

PALAVRAS CHAVE. Brasil, chave de identificação.

Araucaria Jussieu, 1789 trees, the oldest extant conifers, have an evolutionary history stretching more than 200 Mio years. The 19 recent species of this genus have a disjunct distribution (South America and Oceania) and form, under natural conditions, highly diverse mixed forests in tropical and subtropical regions of the Southern Hemisphere. Both the high geological age and the disjunct distribution predestinate Araucaria trees for evolutionary biological studies of insect-plant relationships. Today, we know several insect groups restricted in their occurrence to recent Araucariaceae like the leaf beetle subfamily Palophaginae (Megalopodidae), the weevil tribe Araucariini (Cossoninae, Curculionidae) or the bark or ambrosia beetle genera Hylurdrectonus Schedl, 1938, Hylurgonotus Schedl, 1951, Pachycotes Sharp, 1877 and Xylechinosomus Schedl, 1963 (Scolytinae, Curculionidae) (Kuschel 1966, Kuschel \& MaY 1996, MecKe 2000, WoOd 1986). An important question is, if there already existed Araucaria-insect associations before the splitting of Gondwana began and the continents were completely separated and if so, how these insects evolved in their long distant biogeographical regions. To answer these ques-

Revista Brasileira de Zoologia 21 (3): 505-513, setembro 2004 
tions first of all detailed descriptions of the entomofauna associated with Araucaria trees in South America and Oceania are required. Because of the strong relationship between weevils and their host plants, beetles of the superfamily Curculionoidea are perfectly suited to study the co-evolution of Araucaria trees and their insects.

A few years ago, Morrone (1997) and Kuschel (2000) listed the weevils associated with Araucaria araucana (Molina) C. Koch in Chile, one of the two South American Araucaria trees. To enable future comparisons between the weevil faunas of different Araucaria species, we present here an annotated list of the Curculionoidea associated with Araucaria angustifolia (Bert.) O. Kuntze in Brazil including a key to enable the identification of adult weevils found on this host tree.

\section{MATERIAL AND METHODS}

The data for this study were obtained from a bibliographic survey and own field collections. The field study was realized March 1997 through August 2000 in the Araucaria forest reserve Pró-Mata, located in the municipality of São Francisco de Paula, Rio Grande do Sul, Brazil. The collections were performed mainly using photoeclectors (emergence traps) filled with pieces of dead Araucaria angustifolia wood. A detailed description of the sampling methods is given in MЕскE et al. (2001). All collected specimens are deposited in the entomological collections of the Laboratório de Pesquisas Biológicas, Pontifícia Universidade Católica, Porto Alegre, Rio Grande do Sul, Brazil (LPB) and the Museu de Ciências Naturais, Fundação Zoobotânica, Porto Alegre, Rio Grande do Sul, Brazil (MCNZ).

The classification of Curculionoidea families and subfamilies follows Kuschel (1995). The system (including all taxonomic information) of Curculionidae (except for Scolytinae and Platypodinae), Brentidae and Nemonychidae follows ALonsoZARAZAGA \& Lyal (1999), the system of Scolytinae and Platypodinae follows BRIGHT \& SKIDMORE (1997) and WoOd \& BRIGHT (1992).

For the elaboration of the key specimens of our field study were used and the following literature was consulted: EGGERS (1928), Kuschel $(1966,1995,2000)$ Kuschel \& May (1997), MecKe (2000, 2002, 2004), SCHEdL (1972), Wood $(1982,1986)$ and Wood $\&$ BRIGHT (1992). Unless otherwise indicated measurements of body length exclude the rostrum. Rostrum length is measured laterally from the front margin of the eyes to the distal margin of the epistome.

\section{RESULTS AND DISCUSSION}

The currently known Curculionoidea associated with Araucaria angustifolia trees belong to 43 species of 23 genera of the families Nemonychidae, Brentidae and Curculionidae (Tab. I). Within the family Curculionidae the four subfamilies Curculioninae, Cossoninae, Scolytinae and Platypodinae are represented. The following key enables the identification of adult weevils found on this tree species.
Key to the genera or species of Curculionoidea associated with Araucaria angustifolia

1. Antennae straight ............................................................. 2

1 '. Antennae geniculate .......................................................... 4

2. Pronotum as long as broad or broader than long, labrum not fused with clypeus ..................................................... 3

2 '. Pronotum more than $1.5 \mathrm{x}$ longer than broad, beetles very elongate. 5.0-7.5 $\mathrm{mm}$ (including rostrum) Taphroderes sahlbergi

3. Rostrum more than $3 \mathrm{x}$ longer than its distal width. Head much narrower than pronotum. Antennae filiform, not distinctly enlarged at the end. $4.8 \mathrm{~mm}$

Rhynchitoplesius eximius

$3^{\prime}$.Head not prolonged into rostrum. Head as broad as Pronotum. Three last antennal segments dilated, forming a divided club. $1.8-3.2 \mathrm{~mm}$ Brarus mystes

4. Rostrum very short to nonexistent .................................. 5

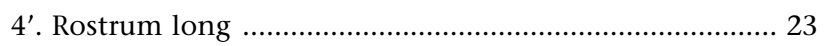

5. First tarsal segment elongate, nearly as long as or even longer than 2-5 combined .

5'. First tarsal segment not elongate ...................................... 8

6. Head, pronotum and elytra with dense erect pilosity. First antennal segment with conspicuous long and dense hairs. 4-9 $\mathrm{mm}$. Tesserocerus spp.

6'. Without conspicuous pilosity 7

7. Protibiae with a strong apical spine. Procoxae slightly separated. 4-9 mm Platypus spp.

7 '. Protibiae without strong apical spine. Procoxae contiguous. $4-5 \mathrm{~mm}$ .Cenocephalus thoracicus

8. Lateral margins of tibiae unarmed except for one apical spinelike process. Head, pronotum and elytra deeply punctuated. Elytra with rows of spikes directed backwards. 2.8$3.5 \mathrm{~mm}$ Eurycorynophorus scabriculus

$8^{\prime}$. Lateral margin of tibiae armed by more than one denticle.

9. Head partly visible from above. Third tarsal segment bilobed ......................................................................... 10

9'. Head completely covered by pronotum, head invisible from above. Third tarsal segment not bilobed 13

10. Pronotum densely pubescent. Antennal funicle 7-segmented. 1.4-3.7 $\mathrm{mm}$ Xylechinosomus spp.

$10^{\prime}$. Pronotum shiny, without conspicuous pubescence. Antennal funicle 5-6-segmented. .. 11

11. Antennal funicle 5-segmented, club strongly asymmetrical, deeply divided into three movable segments, 1.5-3.0 mm.. Phloeotribus spp.

$11^{\prime}$. Antennal funicle 6-segmented, club symetrical, moderately flattened 12 
12. Body oval, about $2 \times$ longer than wide. Pronotum wider than long. Declivity with very short hairs. 2.0-2.6 $\mathrm{mm}$... Pagiocerus punctatus

12 '. Body more elongate, about $3 \mathrm{x}$ longer than wide. Pronotum as long as or longer as wide. Declivity with long erect hairs. 2.2-2.5 mm Cnesinus dividuus

13. Antennal club obliquely truncate. Declivity often armed with tubercles. Elytral apex entire. 2.0-3.7 mm .. 14

13 '. Antennal club strongly flattened. Declivity generally not armed with distinct tubercles (when armed, elytral apex divaricate) 16

14. Scutellar area of elytra distinctly emarginate, scutellum displaced slightly cephalad into a visible, conical process.. Xyleborinus spp.

$14^{\prime}$. Scutellar area of elytra not emarginated, suture of scutellum flush with adjacent surface of elytra .... .. 15

15. Body short, about 2.0-2.3 x longer than wide. Pronotum wider than long Ambrosiodmus catharinensis

15'. Body more elongate, about 2.6-3.0 x longer than wide. Pronotum as long as or longer than wide .. Xyleborus spp.

16. Costal margin of elytra ascending from base of declivity to apex 17

$16^{\prime}$. Costal margin of elytra descending towards apex ....... 18

17. Elytra with sparse erect pilosity. Anterior margin of pronotum with 10-16 crenulations. $1.6-2.3 \mathrm{~mm}$ Cryptocarenus seriatus

17'. Elytra with conspicuous thick scale like hairs. Anterior margin of pronotum with 1-8 crenulations. 0.8-1.3 mm . Hypothenemus eruditus

18. Funicle 5-segmented. Antennal club symmetrical. 1.4$1.8 \mathrm{~mm}$ .. 19

18 '. Funicle 1 or 2 -segmented. Antennal club asymmetrical. 2.4-4.0 mm .. 20

19. Reddish-brown, declivity without setae. $1.4-1.8 \mathrm{~mm}$........ Pityophthorus anticus

$19^{\prime}$. Reddish brown, declivity with small, erect setae. $1.6 \mathrm{~mm}$.. . Araptus araucariae

20. Funicle 2-segmented. Declivity excavated and armed by distinct spines on lateral margin. Elytral apex divaricate. 2.6-3.1 $\mathrm{mm}$ Monarthrum brasiliensis

$20^{\prime}$. Funicle 1-segmented. Declivity convex or weakly excavated, without or with very minute spines. Elytral apex entire. 2.4-4.0 mm (Corthylus spp.).

21. Declivity very abrupt, vertical, concave with elevated margin all around (abdomen barrel shaped). 3.3-4.0 $\mathrm{mm}$...... Corthylus praealtus

21 '. Margin of declivity at least on upper side not elevated. Smaller species $(2.4-3.0 \mathrm{~mm})$ .. 22

22. Declivity nearly vertical, covered with long hairs, dull. Pronotum and elytra coarse punctate. $2.4-2.7 \mathrm{~mm}$ C. rufopilosus
22 '. Declivity moderately descending, covered with fewer hairs, shiny. Pronotum and elytra very minute punctate. 2.9-3.0 $\mathrm{mm}$ C. papulans

23. Larger species, tibiae without articulated spines (7-13 mm)..24 $23^{\prime}$. Small species, tibiae with articulated spines (2.0-4.1 mm)..25

24. Uniformly dark reddish brown, elytra rounded, without declivity, 7-9 mm (Rostrum 2.1-2.8 mm)...Spermologus rufus

24 '. White stripe (formed by scales) from middle of pronotum to scutellum. Pronotum and elytra with coarse granulation. Elytra with abrupt declivity. 10-13 mm (Rostrum 3.0$4.0 \mathrm{~mm})$. Heilipodus tuberculatus

25. Hind femur distinctly widened at base. Rostrum 3.3-4.7 x longer than distal width and 1.2-1.4 $\mathrm{x}$ shorter than prothorax. 3.1-4.1 mm ........................ Araucarius brasiliensis

$25^{\prime}$. Hind femur not widened at base .................................. 26

26. Small, 2.0-2.2 mm. Rostrum 2.5-2.8 x longer than its distal width, 1.4-1.6 $\mathrm{x}$ shorter than prothorax. Elytra and pronotum coarse and deep punctate ........................ A. kuscheli

$26^{\prime}$. Larger species, 2.4-3.1 $\mathrm{mm}$........................................ 27

27 . Elytra and pronotum very coarse and deep punctate. Rostrum 2.8-3.7 x longer than its distal width. 2.7-3.1 mm .. A. crassipunctatus

$27^{\prime}$. Elytra only very shallow and fine punctate. Rostrum 3.1$4.0 \mathrm{x}$ longer than its distal width. 2.4-2.9 mm ... A. ruehmi

\section{Nemonychidae, Rhinorhynchinae, Mecomacerini Brarus mystes Kuschel, 1997}

Known from Paraná and Rio Grande do Sul (Kuschel \& May 1997, Mecke et al. 2001). Very common and in high abundances on male cones of Araucaria angustifolia. Adults and larvae pollen-feeding (Kuschel \& MAY 1997).

\section{Rhynchitoplesius eximius (Voss, 1937)}

Rhynchitomacer eximius Voss, 1937

Known from Paraná and São Paulo. Larvae develop in male cones of Araucaria angustifolia feeding on pollen. When male cone is liberating pollen, larvae leave the cone and hide themselves in the soil. Pupation 5-8 months later in the soil (Costa et al. 1988, Kuschel \& MAY 1997).

\section{Brentidae, Taphroderinae Taphroderes sahlbergi (Sharp, 1895)}

Abactrus sahlbergi Sharp, 1895

Known from Rio Grande do Sul (Mecke et al. 2001) and the city "Santa Rita" (SHARP 1895; we are not able to indicate the Brazilian federal state as there are about 15 Santa Rita in Brazil). Adults enter existing galleries (e.g. from bark beetle Corthylus praealtus) in dead Araucaria angustifolia branches to lay their eggs. Larval tunnels $3.5-4.5 \mathrm{~cm}$ long with increasing diameter. At the end, larvae turn back and pupate about $2 \mathrm{~cm}$ from the entrance of their own gallery. Galleries filled with a 
Table I. Weevils (Curculionoidea) occurring on Araucaria angustifolia in South Brazil (Species with uncertain host relation to this tree species are given in squared brackets).

\begin{tabular}{|c|c|}
\hline Family/Subfamily & Species \\
\hline \multirow[t]{2}{*}{ Nemonychidae } & Brarus mystes Kuschel, 1997 \\
\hline & Rhynchitoplesius eximius (Voss, 1937) \\
\hline Brentidae & Taphroderes sahlbergi (Sharp, 1895) \\
\hline \multicolumn{2}{|l|}{ Curculionidae } \\
\hline \multirow[t]{2}{*}{ Curculioninae } & Heilipodus tuberculatus (Boheman, 1836) \\
\hline & Spermologus rufus Boheman, 1843 \\
\hline \multirow[t]{5}{*}{ Cossoninae } & Araucarius brasiliensis Kuschel, 1966 \\
\hline & A. crassipunctatus Mecke, 2000 \\
\hline & A. kuscheli Mecke, 2000 \\
\hline & A. ruehmi Kuschel, 1966 \\
\hline & Eurycorynophorus scabriculus Voss, 1964 \\
\hline \multirow[t]{27}{*}{ Scolytinae } & Ambrosiodmus catharinensis (Eggers, 1928) \\
\hline & Araptus araucariae (Schedl, 1966) \\
\hline & Cnesinus dividuus Schedl, 1938 \\
\hline & Corthylus papulans Eichhoff, 1868 \\
\hline & C. praealtus Schedl, 1976 \\
\hline & C. rufopilosus Eggers, 1931 \\
\hline & Cryptocarenus seriatus Eggers, 1933 \\
\hline & Hypothenemus eruditus Westwood, 1836 \\
\hline & Monarthrum brasiliensis (Schedl, 1936) \\
\hline & Pagiocerus punctatus Eggers, 1928 \\
\hline & Phloeotribus argentinensis (Schedl, 1951) \\
\hline & P. cylindricus Schedl, 1951 \\
\hline & Pityophthorus anticus Schedl, 1976 \\
\hline & Xylechinosomus brasiliensis (Schedl, 1951) \\
\hline & X. contractus (Chapuis, 1873) \\
\hline & X. hirsutus Schedl, 1963 \\
\hline & X. lucianae Mecke, 2004 \\
\hline & X. minimus Schedl, 1963 \\
\hline & X. paranaensis (Schönherr, 1994) \\
\hline & X. pilosus Wood, 1985 \\
\hline & [X. sachtebeni Schedl, 1963] \\
\hline & Xyleborus adelographus Eichhoff, 1868 \\
\hline & X. affinis Eichhoff, 1867 \\
\hline & X. ferrugineus (Fabricius, 1801) \\
\hline & X. volvulus (Fabricius, 1775) \\
\hline & Xyleborinus linearicollis (Schedl, 1937) \\
\hline & $X$. sentosus (Eichhoff, 1868) \\
\hline \multirow[t]{6}{*}{ Platypodinae } & Cenocephalus thoracicus Chapuis, 1865 \\
\hline & Platypus araucariae Schedl, 1966 \\
\hline & P. mutatus Chapuis, 1865 \\
\hline & P. parallelus (Fabricius, 1801) \\
\hline & [Tesserocerus guerini Chapuis, 1865] \\
\hline & T. insignis Saunders, 1936 \\
\hline
\end{tabular}

clear and strongly compressed frass. Emerging adults pass through the existing gallery to escape (МескE et al. 2001).

\section{Curculionidae, Curculioninae, Hylobiini Heilipodus tuberculatus (Boheman, 1836)}

Heilipus tuberculatus Boheman, 1836

Known from Rio Grande do Sul (MескE et al. 2000, 2001). Since $H$. tuberculatus was formerly placed into the genus Heilipus Germar, 1824 (Wibmer \& O'Brien 1986), it might be the same species mentioned by Zajciw (1962) as "Heilipus sp." from Araucaria angustifolia in Santa Catarina and Rio Grande do Sul. The larvae developed under the bark of felled Araucaria trees, shrubs or dead branches, adults emerged from December-June (Меске et al. 2001, ZAJCIW 1962).

\section{Curculionidae, Curculioninae, Petalochilini Spermologus rufus Boheman, 1843}

Known from Brazil (Minas Gerais) and Argentina (BARRETO et al. 1999, Wibmer \& O’Brien 1986). Larvae develop inside the seeds of Araucaria angustifolia and seeds of several other plants like Theobroma cacao Linné (Sterculiaceae) or Virola oleifera Schott (Myristicaceae) (Barreto \& dos Anjos 2002, Barreto et al. 1999, BONDAR 1943).

\section{Curculionidae, Cossoninae, Araucariini Araucarius brasiliensis Kuschel, 1966}

Known from Santa Catarina and Rio Grande do Sul (MECKE et al. 2000, Kuschel 1966). Adults and larvae in the phloem of dead Araucaria angustifolia branches, rarely found in the phloem of dead trunks. Larvae and adults phloeophagous, for pupation larvae drill a short tunnel into the wood. Pupae found in sealed holes with head towards exit. Adults emerged across the whole year with a maximum from November to January (МескE et al. 2000, 2001).

\section{Araucarius crassipunctatus Mecke, 2000}

Known from Rio Grande do Sul. Adults and larvae in the phloem of dead Araucaria angustifolia branches, rarely found in the phloem of dead trunks. Larvae and adults phloeophagous. Adults emerged from October - February with a maximum in December (Меске 2000, Меске et al. 2000, 2001).

\section{Araucarius kuscheli Mecke, 2000}

Known from Rio Grande do Sul. Adults and larvae in the phloem of dead Araucaria angustifolia branches. Larvae and adults phloeophagous. Adults emerged across the whole year with maximums in October and January/February (MECKE 2000, MECKE et al. 2000, 2001).

\section{Araucarius ruehmi Kuschel, 1966}

Known from Santa Catarina and Rio Grande do Sul (Mecke et al. 2000, Kuschel 1966). Adults and larvae in the 
phloem of dead Araucaria angustifolia branches, rarely found in the phloem of dead trunks. Larvae and adults phloeophagous. Adults emerged from October to February (Mecke et al. 2000, 2001).

\section{Curculionidae, Cossoninae, Onycholipini Eurycorynophorus scabriculus Voss, 1964}

Known from Paraná and Rio Grande do Sul (Mecke et al. 2000, Voss 1964). Adults and larvae mine in the wood of dead branches, probably xylomycetophagous. Galleries very similar to those of Scolytinae, comprising a parental gallery, eggniches and larval tunnels. Adults emerged from Araucaria angustifolia wood samples (branches) from August to February (Меске et al. 2000, 2001).

\section{Curculionidae, Scolytinae, Tomicini}

Several authors included the following species of the genus Xylechinosomus Schedl, 1963 into Pteleobius Bedel, 1888 and most records relate to that genus (SCHEDL 1966a, b, 1976, Schönherr 1994, Schönherr \& Pedrosa-Macedo 1981, PedrosaMACEDO \& SCHÖNHERR 1985). However, according to WOOD \& BRIGHT (1992) the correct position of these species is in the genus Xylechinosomus.

\section{Xylechinosomus brasiliensis (Schedl, 1951)}

Pseudohylesinus brasiliensis Schedl, 1951

Synonym: Xylechinosomus araucariae Schedl, 1963.

Known from Paraná, Rio Grande do Sul and Santa Catarina (Mecke et al. 2000, SCHEdL 1963, 1976). Monogamous and phloeophagous (WOoD 1986). Galleries in the phloem of Araucaria angustifolia branches (МескE et al. 2000, 2001, SCHEDL 1966a).

\section{Xylechinosomus contractus (Chapuis, 1873)}

Hylastes contractus Chapuis, 1873

Synonym: Xylechinus taunayi Eggers, 1928.

Known from Mato Grosso, Minas Gerais, Paraná, Rio Grande do Sul, Santa Catarina and São Paulo (Eggers 1928, MECKE et al. 2000, 2001, Schedl 1966b, 1976, Schönherr \& PedrosaMACEDO 1981). Monogamous and phloeophagous (WOOD 1986). Galleries in the phloem of branches or dead trunks or inside of seeds (Mecke et al. 2001, Schönherr \& Pedrosa-Macedo 1981). It has been also found in the bark of Pinaceae (Pinus spp.) (Schönherr \& Pedrosa-Macedo 1981), Ulmaceae (Trema sp.), Phytolaccaceae (Phytolacca dioica Linné) (SCHEDl 1966b).

\section{Xylechinosomus hirsutus Schedl, 1963}

Known from Paraná, Rio Grande do Sul and Santa Catarina (Mecke et al. 2000, 2001, SChedL 1963, SchöNherR \& Pedrosa-Macedo 1981). Monogamous and phloeophagous (Wood 1986). Galleries in the phloem of Araucaria angustifolia branches or inside of buds or seeds (MECKE et al. 2001, SCHÖNHERR \& Pedrosa-Macedo 1981).

\section{Xylechinosomus Iucianae Mecke, 2004}

Known from Rio Grande do Sul, where it was very abundant under the bark of small branches and twigs of Araucaria angustifolia (МЕСКe et al. 2001, МЕСКE 2004).

\section{Xylechinosomus minimus Schedl, 1963}

Known from Minas Gerais, Paraná, Rio Grande do Sul, Santa Catarina, São Paulo (Mecke et al. 2000, 2001, PedrosaMaCEdo \& SCHÖNherR 1985, SCHedl 1963, 1976). Monogamous and phloeophagous (WOoD 1986). Galleries mostly in the phloem of branches, sometimes also in the phloem of dead trunks, inside of seeds or in male cones (Меске et al. 2001, SCHÖNherR \& Pedrosa-Macedo 1981).

\section{Xylechinosomus paranaensis (Schönherr, 1994)}

Pteleobius paranaensis Schönherr, 1994

Known from Paraná and Rio Grande do Sul (Меске et al. 2001, SCHÖNHERR 1994) Monogamous and phloeophagous (Wood 1986). Galleries mostly in the phloem of branches, sometimes also in the bark of dead trunks (МЕске et al. 2001, SCHÖNHERR 1994).

\section{Xylechinosomus pilosus Wood, 1985}

Known from Paraná, where two specimens, the holo- and one allotype were taken in Araucaria angustifolia bark (WOOD 1985).

\section{Xylechinosomus sachtlebeni Schedl, 1963}

Known from Santa Catarina (SCHedl 1963). Monogamous and phloeophagous (Wood 1986). SCHÖNHERR (1994) and WoOD (1986) affirmed that all Xylechinosomus species are phloeophagous in Araucaria species (A. angustifolia in Brazil/Argentina and A. araucana in Chile/Argentina) but there is no confirmed host record for $X$. sachtlebeni.

\section{Curculionidae, Scolytinae, Bothrosternini Cnesinus dividuus Schedl, 1938}

Synonyms: Cnesinus dryographus Schedl, 1951; C. laevicollis Schedl, 1951.

Known from Bahia, Minas Gerais, Paraná and Santa Catarina (Pedrosa-Macedo \& Schönherr 1985, Schedl 1951a, 1976, Wood \& BRIght 1992). Wood (1986) indicates, that most species of Cnesinus LeConte, 1868 are "myelophagous except that one is partly phloeophagous". PEDROSA-MACEDO \& SCHÖNHERR (1985) found beetles of C. dividuus "in Araucaria angustifolia". It is also known from Malvaceae (Gossypium sp.) (SCHEDL 1966b) and has been caught in Eucalyptus dunii Maiden (Myrtaceae) and Pinus caribea Linné (Pinaceae) reforestations (PedrosaMACEDO \& SCHÖNHERR 1985).

\section{Pagiocerus punctatus Eggers, 1928}

Known from Mato Grosso, Paraná and Santa Catarina (EGgers 1928, SCHEDL 1966b, 1976). Wood (1986) indicates, that 
all species of Pagiocerus Eichhoff, 1868 are spermophagous but Schönherr \& Pedrosa-Macedo (1981) found P. punctatus developing in male cones of Araucaria angustifolia. It is also known from trunks of Luehea divaricata Martius (Tiliaceae) and from trunks and seeds of Ocotea porosa Nees \& Martius and O. puberula Rich. (Lauraceae) (Schönherr \& Pedrosa-Macedo 1981).

\section{Curculionidae, Scolytinae, Phloeotribini Phloeotribus argentinensis (Schedl, 1951)}

Phthorophloeus argentinensis Schedl, 1951

Known from Santa Catarina, Brazil and Misiones, Argentina (Schedl 1977, Viana 1965, Wood \& Bright 1992). According to Wood (1986) all Phloeotribini are monogamous and phloeophagous, but VIANA (1965) recorded this species feeding on seeds of Araucaria angustifolia.

\section{Phloeotribus cylindricus Schedl, 1951}

Known from Santa Catarina, Brazil and Misiones, Argentina and (Viana 1965, Schedl 1951a, 1958). Viana (1965) found P. cylindricus in branches of Araucaria angustifolia.

\section{Curculionidae, Scolytinae, Xyleborini Ambrosiodmus catharinensis (Eggers, 1928)}

Xyleborus catharinensis Eggers, 1928

Known from Paraná, Rio Grande do Sul, Santa Catarina and São Paulo (Eggers 1928, Mecke et al. 2001, SChÖNHERR \& Pedrosa-Macedo 1981). Mecke et al. (2001) recorded this xylomycetophagous species from Araucaria angustifolia branches in Rio Grande do Sul, Schönherr \& Pedrosa-Macedo (1981) from Cedrela fissilis Vellozo (Meliaceae) and Pinus elliottii Engelm. (Pinaceae).

\section{Xyleborinus linearicollis (Schedl, 1937)}

Xyleborus linearicollis Schedl, 1937

Known from Minas Gerais, Paraná, Santa Catarina, São Paulo and from Buenos Aires, Argentina (SCHEdL 1958, 1966b, 1976, Pedrosa-MaCEDo \& SCHÖNHERR 1985). Galleries in branches of Araucaria angustifolia and in Eucalyptus robusta Smith, E. camaldulensis Dehnh., E. tereticornis Smith (Myrtaceae) and Pinus elliottii (Pinaceae) (Bright \& Skidmore 1997, Schedl 1966b, SChÖNherr \& Pedrosa-Macedo 1981).

\section{Xyleborinus sentosus (Eichhoff, 1868)}

Xyleborus sentosus Eichhoff, 1868

Known from Argentina (Misiones), Brazil (Ceará, Mato Grosso, Minas Gerais, Paraná, Rio Grande do Sul, Santa Catarina, São Paulo), Paraguay and Peru (SCHEdL 1951b, 1966b, 1976, Wood \& BRIGHT 1992). SCHEdl (1966a) recorded this species from Araucaria angustifolia in Santa Catarina, SCHÖNHERR \& Pedrosa-Macedo (1981) from Cedrela fissilis.

\section{Xyleborus Eichhoff, 1864}

All of the several hundred species belonging to the genus Xyleborus are consanguineously polygynous and xylomy- cetophagous (Wood 1986). Therefore, all species are at least oligo- or even polyphagous.

Wood \& BRIGHT (1992) listed in their catalog Araucaria angustifolia as a host for Xyleborus perforans (Wollaston, 1857). But as this bark beetle species has never been recorded from South America (BRIGHT \& SKIDMORE 1997, WoOd \& BRIGHT 1992), it has been cited erroneously in the host list or has been found on planted trees.

\section{Xyleborus adelographus Eichhoff, 1868}

Synonyms: Xyleborus vitiosus Schedl, 1940; X. accomodatus Schedl, 1966.

Known from Argentina, Brazil, Cayenne, Colombia, Guyana, Paraguay (Wood \& BRIGHT 1992). Developing in seeds of Araucaria angustifolia. Also recorded from Pinus elliottii (Pinaceae) (Schönherr \& Pedrosa-Macedo 1981) and Couma macrocarpa Barb. Rodr. (Apocynaceae) (Wood \& BRIgHT 1992).

\section{Xyleborus affinis Eichhoff, 1867}

Synonyms: Xyleborus sacchari Hopkins, 1915; X. subaffinis Eggers, 1933; X. societatis Beeson, 1935; X. proximus Eggers, 1943.

Nearly worldwide distributed (except for Europe) and extremely polyphagous with over 270 angio- and gymnospermous host species (Wood 1982, Wood \& BRIgHT 1992). SCHEdL (1976) recorded this species from Araucaria angustifolia in Paraná.

\section{Xyleborus ferrugineus (Fabricius, 1801)}

Bostrichus ferrugineus Fabricius, 1801

Synonyms: Xyleborus fuscatus Eichhoff, 1868; X. impressus Eichhoff, 1868; X. confusus Eichhoff, 1868; X. retusicollis Zimmermann, 1868; X. bispinatus Eichhoff, 1868; X. amplicollis Eichhoff, 1869; X. insularis Sharp, 1885; X. tanganus Hagedorn, 1910; X. soltaui Hopkins, 1915; X. nyssae Hopkins, 1915; X. hopkinsi Beeson, 1929; X. argentinensis Schedl, 1931; X. rufopiceus Eggers, 1932; X. schedli Eggers, 1934; X. nesianus Beeson, 1940; X. notatus Eggers, 1941; X. subitus Schedl, 1948.

Widely distributed in tropical and subtropical American and African regions. Polyphagous with about 200 host species and considered to be one of the most destructive bark beetle species in tropical regions (WOOD 1982). The beetles prefer angiospermous host trees but were also found in conifers like Araucaria angustifolia and Pinus elliottii. In Araucaria trees the galleries were in the branches and inside of female cones (Schönherr \& Pedrosa-Macedo 1981).

\section{Xyleborus volvulus (Fabricius, 1775)}

Bostrichus volvulus Fabricius, 1775

Synonyms: Xyleborus torquatus Eichhoff, 1868; X. alternans Eichhoff, 1869; X. badius Eichhoff, 1869; X. interstitialis Eichhoff, 1878; X. guanaguatensis Duges, 1887; X. hubbardi Hopkins, 1915; X. schwarzi Hopkins, 1915; X. rileyi Hopkins, 
1915; X. grenadensis Hopkins, 1915; X. silvestris Beeson, 1929; X. vagabundus Schedl, 1948; X. granularis Schedl, 1950.

Worldwide distributed and polyphagous with about 160 gymnospermous and angiospermous host species (Wood 1982, WoOd \& BRIGHT 1992).

\section{Curculionidae, Scolytinae, Cryphalini Cryptocarenus seriatus Eggers, 1933}

Synonyms: Cryptocarenus adustus Eggers, 1933; Tachyderes floridensis Blackman, 1943; Cryptocarenus bolivianus Eggers, 1943.

Known from North and South America from about 20 host trees (BRight \& SKIDMORE 1997, WoOd \& BRIGHT 1992). SCHÖNHERR \& Pedrosa-Macedo (1981) found the beetles inside of thin Araucaria angustifolia twigs.

\section{Hypothenemus eruditus Westwood, 1836}

This is a very common and worldwide distributed bark beetle, with several hundred known hosts including fungi, grasses, weeds and trees and with about 70 synonyms (WooD 1982, Wood \& BRIGHT 1992). The beetles and larvae were also found inside of thin twigs of Araucaria angustifolia (SCHEDL 1976, SCHÖNherr \& Pedrosa-Macedo 1981).

\section{Curculionidae, Scolytinae, Corthylini Araptus araucariae (Schedl, 1966)}

Conophthocranulus araucariae Schedl, 1966

SCHEDL (1966b) recorded this species from seeds of Araucaria angustifolia in Misiones (Argentina).

\section{Corthylus papulans Eichhoff, 1869}

Synonyms: Corthylus affinis Fonseca, 1925; C. guayanensis Eggers, 1933; C. tomentosus Schedl, 1940.

Known from Antilles Islands, North and South America (Mecke et al. 2000, Pedrosa-Macedo \& Schönherr 1985, Schedl 1967, Wood \& BRIGHT 1992). Polyphagous in several angiospermous host trees (BRIGHT \& SKIDMORE 1997, WoOd \& BRIGHT 1992). Found also in the wood of Araucaria angustifolia branches (MECKE et al. 2001).

\section{Corthylus praealtus Schedl, 1976}

Known from Paraná and Rio Grande do Sul (МескE et al. 2000, Schedl 1976). Galleries in branches of Araucaria angustifolia. Parental tunnel circling around the centre of the branch, larval tunnels branching off parallel to the surface. Males building the entrance tunnel, females enter later and help to remove the frass. Immature adults with their heads to the closed ends of the larval cradles, emerging backwards through the parental tunnel (МЕскE et al. 2001).

\section{Corthylus rufopilosus Eggers, 1931}

Known from Santa Catarina, São Paulo and Rio Grande do Sul (EgGers 1931, Mecke et al. 2000, Schedl 1954). Galleries in branches of Araucaria angustifolia. Parental tunnel circling around the centre of the branch, larval tunnels branching off parallel to the surface. Immature adults with their heads at the closed ends of the larval cradles, emerging backwards through the parental tunnel. Galleries very similar to those of $C$. praealtus but with smaller diameter (МеСКE et al. 2001).

\section{Monarthrum brasiliensis (Schedl, 1936)}

Anchonocerus brasiliensis Schedl, 1936

Known from Paraná and Santa Catarina. Larval development inside of female cones of Araucaria angustifolia. (PedrosaMacedo \& Schönherr 1985, Schönherr \& Pedrosa-Macedo 1981).

\section{Pityophthorus anticus Schedl, 1976}

Known from Paraná and Rio Grande do Sul (Mecke et al. 2001, SCHEDL 1976). Larvae develop in branches of young Araucaria angustifolia trees as well as inside of male and female cones. Also found in branches of Ocotea puberula and Pinus elliottii (MЕCKE et al. 2001, Pedrosa-Macedo \& Schönherr 1985, Schedl 1976).

\section{Curculionidae, Platypodinae, Tesserocerini Cenocephalus thoracicus Chapuis, 1865}

Known from Rio de Janeiro and Santa Catarina (CHapus 1865). SCHEDL (1966a) recorded this species from trunks of Araucaria angustifolia in Santa Catarina.

\section{Tesserocerus guerini Chapuis, 1865}

Known from Argentina, Bolivia, Brazil, Cayenne and French Guyana (SCHEdL 1970, 1972, Wood \& BRIGHT 1992). According to Schönherr \& Pedrosa-Macedo (1981) it is "probable", that this species also develops in Araucaria angustifolia and WOOD \& BRIght (1992) listed A. angustifolia as a host for T. guerini but were supposedly referring to SCHÖNHERR \& PEDROSA MACEDo (1981). Therefore it remains doubtful whether T. guerini accepts Araucaria angustifolia as a host tree or not. Confirmed hosts for this species are Cedrela fissilis (Meliaceae), Eschweilera sagotiana Miers (Lecythidaceae) and Ocotea sp. (Lauraceae) (Wood \& BRIGHT 1992).

\section{Tesserocerus insignis Saunders, 1936}

Synonyms: Tesserocerus bihamatus Guérin-Meneville, 1838; Tesseroplatypus ursus Schedl, 1935.

Known from Argentina, Bolivia, Brazil, Paraguay and Uruguay (SCHEdl 1966a, b, 1970, 1972, Wood \& Bright 1992). SCHEDL (1966a) recorded this species from trunks of Araucaria angustifolia in Santa Catarina. Another host is Cedrela fissilis (Meliaceae) (Schedl 1976, Schönherr \& Pedrosa-Macedo 1981).

\section{Curculionidae, Platypodinae, Platypodini Platypus araucariae Schedl, 1966}

Known from Amazonas, Paraná, Santa Catarina and Rio Grande do Sul (Schedl 1966a, Schönherr \& Pedrosa-Macedo 1981). Galleries in trunks of Araucaria angustifolia and Anacar- 
dium occidentale Linné (Anacardiaceae) (SchedL 1966a, b). Parental galleries horizontally, deep in the wood, larval tunnels vertically (Schönherr \& Pedrosa-Macedo 1981).

\section{Platypus mutatus Chapuis, 1865}

Synonyms: Platypus sulcatus Chapuis, 1865; P. plicatus Brèthes, 1909.

Known from Argentina, Bolivia, Brazil, Cayenne, Paraguay, Peru, Uruguay and Venzuela (SCHEDL 1950, 1951b, 1966b, 1976, 1977, Wood \& BRIgHT 1992). Mostly angiospermous hosts (Schedl 1950, Schönherr \& Pedrosa-Macedo 1981, Wood \& Bright 1992). SCHÖNherr \& Pedrosa-Macedo (1981) recorded this species from trunks of Araucaria angustifolia in Paraná. The galleries with a diameter of 2.5-3 $\mathrm{mm}$ are organized in horizontal systems.

\section{Platypus parallelus (Fabricius, 1801)}

Bostrichus parallelus Fabricius, 1801

Synonyms: Platypus linearis Stephens, 1830; P. poeyi Guerin-Meneville, 1838; P. subcostatus Jacquelin-Duval, 1857; P. dejeani Chapuis, 1865; P. marseuli Chapuis, 1865; P. proximus Chapuis, 1865; P. compressus Chapuis, 1865; P. regularis Chapuis, 1865; P. rugulosus Chapuis, 1865; P. reticulatus Chapuis, $1865 ; P$. rotundatus Chapuis, 1865; P. kraatzi Chapuis, 1865; P. lebasi Chapuis, 1865; P. emarginatus Chapuis, 1865; P. punctulatus Chapuis, 1865; P. subaequalis Chapuis, 1865; P. wesmaeli Chapuis, 1865; P. oblongus Chapuis, 1865; P. difficilis Chapuis, 1865; P. praevius Chapuis, 1865; P. maeklini Chapuis, 1865; P. erichsoni Chapuis, 1865; P. laevicollis Chapuis, 1865; P. congoanus Duvivier, 1891; P. triquetrus Brèthes, 1909; P. mattai Brèthes, 1921.

Known from Africa, South and North America (SCHEDL 1966b, 1970, 1972, 1976, Wood \& Bright 1992). Polyphagous, angio- and gymnospermous hosts (SCHEDL 1976, SCHÖNHERR \& Pedrosa-Macedo 1981). Schönherr \& Pedrosa-Macedo (1981) recorded this species from Araucaria angustifolia in São Paulo and Paraná. Also found in female cones of $A$. angustifolia inside the seeds (SChÖNherr \& Pedrosa-Macedo 1981).

\section{ACKNOWLEDGEMENTS}

Access to entomological collections was kindly arranged by J.H. Pedrosa-Macedo (Departamento de Ciências Florestais, UFPR, Curitiba, Brazil), J. Schönherr (Forstzoologisches Institut, Universität Freiburg, Germany), H. Schönmann (Sammlung Schedl, Naturhistorisches Museum, Vienna, Austria) and H. Strümpel (Zoologisches Institut und Zoologisches Museum der Universität Hamburg, Germany).

\section{REFERENCES}

Alonso-Zarazaga, M.A. \& C.H.C. Lyal. 1999. A world catalogue of families and genera of Curculionoidea (Insecta: Coleoptera) (Excepting Scolytidae and Platypodidae). Barcelona, Entomopraxis, 315p.

Barreto, M.R. \& N. Dos Anjos. 2002. Morfologia das diversas fases de desenvolvimento de Spermologus rufus Boheman, 1843 (Coleoptera: Curculionidae) em sementes de Araucaria angustifolia (Bertol.) O. Kuntze. Ciências Agrotecnicas, Lavras, 26 (4): 810-816.

Barreto, M.R.; J.L. Neto \& N. dos Anjos. 1999. Dimorfismo e razão sexual em pupas e adultos de Spermologus rufus Boheman 1843 (Coleoptera: Curculionidae). Ciência e Agrotecnologia, Lavras, 23 (2): 358-364.

Bondar, G. 1943. Notas entomológicas da Baía. XII. Revista de Entomologia, Rio de Janeiro, 14, (1-2): 85-134.

Brigth, D.E. \& R.E. SKidmore. 1997. A catalog of Scolytidae and Platypodidae (Coleoptera), Supplement 1 (19901994). Ottawa, NRC Research Press, VII+368p.

Chapuis, F. 1865. Monographie des Platypides. Liége, Imprimerie de H. Dessain, VI+344p.

Costa, C.; S.A.Vanin \& S.A. CaSari-ChEN. 1988. Larvas de Coleoptera do Brasil. São Paulo, Museu de Zoologia, Universidade de São Paulo, VIII+282p.

Eggers, H. 1928. Ipidae (Coleoptera) da America do Sul. Archivos do Instituto Biológico de Defesa Agricola e Animal, São Paulo, 1: 83-99.

. 1931. Borkenkäfer (Ipidae, Col.) aus Südamerika IV. Wiener Entomologische Zeitung, Wien, 48 (1): 29-42.

KusCHeL, G. 1966. A cossonine genus with bark-beetle habits, with remarks on relationships and biogeography (Coleoptera Curculionidae). New Zealand Journal of Science, Wellington, 9 (1): 3-29.

. 1995. A phylogenetic classification of Curculionoidea to families and subfamilies. Memoir of the Entomological Society of Washington 14: 5-33.

. 2000. La fauna curculiónica (Coleoptera: Curculionoidea) de la Araucaria araucana. Revista Chilena de Entomología, Santiago, 27: 41-51.

Kuschel, G. \& B.M. May. 1996. Discovery of Palophaginae (Coleoptera: Megalopodidae) on Araucaria araucana in Chile and Argentina. New Zealand Entomologist, Nelson, 19: 113.

-1997. A new genus and species of Nemonychidae (Coleoptera) associated with Araucaria angustifolia in Brazil. New Zealand Entomologist, Nelson, 20: 15-22.

Mecke, R. 2000. Two new species of cossonine weevils, Araucarius kuscheli spec. nov. and A. crassipunctatus spec. nov. (Coleoptera: Curculionidae) from Southern Brazil. Studies on Neotropical Fauna and Environment, Lisse, 35 (3): 195-199.

. 2002. Insetos do Pinheiro Brasileiro - Insekten der Brasilianischen Araukarie - Insects of the Brazilian Pine. Tübingen, Attempto Service, 79p.

2004. A new Brazilian bark beetle, Xylechinosomus lucianae sp.n. (Coleoptera, Curculionidae, Scolytinae, Tomicini), from Araucaria angustifolia (Conifera, Araucariaceae). Deutsche Entomologische Zeitschrift, Berlin, 51 (2): 217 220.

Revista Brasileira de Zoologia 21 (3): 505-513, setembro 2004 
Mecke, R.; M.H.M. Galileo \& W. Engels. 2000. Insetos e ácaros associados à Araucaria angustifolia (Araucariaceae, Coniferae) no sul do Brasil. Iheringia, Série Zoologia, Porto Alegre, 88: $165-172$.

. 2001. New records of insects associated with Araucaria trees: Phytophagous Coleoptera and Hymenoptera and their natural enemies. Studies on Neotropical Fauna and Environment, Lisse, 36 (2): 113-124.

Morrone, J.J. 1997. Weevils (Coleoptera: Curculionoidea) that feed on Araucaria araucana (Araucariaceae) in Southern Chile and Argentina, with an annotated checklist. Folia Entomológica Mexicana, Xalapa, 100: 1-14.

Pedrosa-Macedo, J.H. \& J. Schönherr. 1985. Manual dos Scolytidae nos reflorestamentos Brasileiros. Curitiba, Universidade Federal do Paraná, VI+71p.

SCHEDL, K.E. 1950. Neotropical Scolytoidea II-107. Contribution of the morphology and taxonomy of the Scolytoidea. Dusenia, Curitiba, 1 (3): 145-180.

. 1951a. Neotropische Scolytoidea IV-112. Beitrag zur Morphologie und Systematik der Scolytoidea. Dusenia, Curitiba, 2 (2): 71-130.

. 1951b. Fauna Argentinensis V-96. Contribution to the Morphology and Taxonomy of the Scolytoidea. Acta Zoológica Lilloana, Tucumán, 12: 443-463. . 1954. Neotropische Scolytoidea VI-142. Beitrag zur Morphologie und Systematik der Scolytoidea. Dusenia, Curitiba, 5 (1): 21-48.

- 1958. Fauna argentinensis VII-136. Beitrag zur Morphologie und Systematik der Scolytoidea. Acta Zoológica Lilloana, Tucumán, 16: 33-46. . 1963. Neotropische Scolytoidea VII-211. Beitrag zur Morphologie und Systematik der Scolytoidea. Reichenbachia, Dresden, 1 (27): 209-234.

. 1966a. Etwas über die Borkenkäfer der Araucarien 239. Beitrag zur Morphologie und Systematik der Scolytoidea. Anzeiger für Schädlingskunde, Berlin, 39 (3): 42-45.

- 1966b. Neotropische Scolytoidea VIII-238. Beitrag zur Morphologie und Systematik der Scolytoidea. Entomologische Arbeiten aus dem Museum G. Frey, München, 17: 74-128.

. 1967. Neotropische Scolytoidea IX-251. Beitrag zur Morphologie und Systematik der Scolytoidea. Opuscula Zoologica, München, 99: 1-19. 1970. Neotropische Scolytoidea X-270. Beitrag zur Morphologie und Systematik der Scolytoidea. Koleopterologische Rundschau, Wien, 48: 79-110.

— 1972. Monographie der Familie Platypodidae -
Coleoptera. Den Haag, Dr. W. Junk N.V., V+322p. . 1976. Neotropische Scolytoidea XIII (Coleoptera) 323. Beitrag zur Morphologie und Systematik der Scolytoidea. Entomologische Abhandlungen aus dem Staatlichen Museum für Tierkunde, Dresden, 41 (3): 49-92. . 1977. Neotropische Scolytoidea XIV-335. Beitrag zur Morphologie und Systematik der Scolytoidea. Entomologische Abhandlungen aus dem Staatlichen Museum für Tierkunde, Dresden, 41 (8): 291-309.

SCHÖNHERR, J. 1994. Neue Borkenkäfer von Brasilien (Coleoptera, Scolytidae). Deutsche Entomologische Zeitschrift Neue Folge, Berlin, 41 (1): 63-69.

Schönherr, J. \& J.H. Pedrosa-Macedo. 1981. Scolytoidea in den Aufforstungen Brasiliens - Ein Beitrag zur Kenntnis der Borkenkäfer Südamerikas. Zeitschrift für angewandte Entomologie, Berlin, 92: 48-61.

Sharp, D. 1895. Brenthidae, p. 1-80. In: F.D. Godman \& O. Salvin (Eds). Biologia Centrali-Americana. Insecta, Coleoptera. London, Porter, vol. 4, Part 6, VI+396p.

Voss, E. 1964. Cossoninengattungen aus der Verwandtschaft von Stenoscelis Woll. (Coleoptera, Curculionidae) - 186. Beitrag zur Kenntnis der Curculioniden. Reichenbachia, Dresden, 3: 133-143.

VianA, M.J. 1965. Datos ecologicos de Scolytidae Argentinos (Coleoptera). Revista de la Sociedad Entomológica Argentina, Tucumán, 27: 119-130.

Wibmer, G.J. \& C.W. O’Brien. 1986. Annotated checklist of the weevils (Curculionidae sensu lato) of South America (Coleoptera: Curculionoidea). Memoirs of the American Entomological Institute, Gainsville, 39: 1-563.

Wood, S.L. 1982. The bark and ambrosia beetles of North and Central America (Coleoptera: Scolytidae), a taxonomic monograph. Great Basin Naturalist Memoirs, Provo, 6: 11359.

. 1985. New synonymy and new species of bark beetles (Coleoptera: Scolytidae). Great Basin Naturalist, Provo, 45 (2): 266-275.

. 1986. A reclassification of the genera of Scolytidae (Coleoptera). Great Basin Naturalist Memoirs, Provo, 10: 1-126.

Wood, S.L. \& D.E. BRight. 1992. A catalog of Scolytidae and Platypodidae (Coleoptera), Part 2: Taxonomic Index. Great Basin Naturalist Memoirs, Provo, 13: 1-1553.

ZAJCIW, D. 1962. Observações sôbre os insetos nocivos das plantas nos parques florestais do Instituto Nacional do Pinho, nos anos de 1961 e 1962. Anuário Brasileiro de Economia Florestal, Rio de Janeiro, 14: 67-76.

Received in 01.X.2003; accepted in 12.VII.2004.

Revista Brasileira de Zoologia 21 (3): 505-513, setembro 2004 